\title{
In Memoriam Terence Powell
}

Professor T. G. E. Powell-'Terence' Powell as we all knew him, though it appears that the first initial really stood for Thomas-died at the beginning of last Summer in Liverpool after an operation. His loss, deeply felt by archaeologists in Britain and elsewhere in Europe, is made more poignant for members of the Prehistoric Society by the still-fresh memory of his recent term as our President. The great success which he made of this, and even the mere fact that he was able to carry it through to the end, depended, like all his other activities in recent years, on a continual struggle with the effects of prolonged and painful illness, a struggle which he carried on with a determination, gallantry, and even gaiety, which, as Glyn Daniel wrote recently in the pages of Antiquity, earned the admiration of us all.

His life spanned the period during which prehistory became a recognized academic discipline, and his own efforts contributed not a little in various ways to help this development. The fruits of his lifelong dedication to our subject, which he did not trumpet aloud, but quietly and devotedly put into practice, are plain to see. The careful scholarship of his varied range of professional papers, the clarity and lasting freshness of his two popular books, The Celts and Prehistoric Art, and the active group of prehistorians who were his pupils (whether formally his students or not) and who are proud to acknowledge him as their teacher, constitute an enduring achievement which is his most appropriate memorial. No less important, though more evanescent, is the affection which he inspired in his colleagues, who generally found his inexhaustible flow of learning and ideas, salted with a characteristically mischievous Anglo-Irish wit and humour, quite irresistible.

This volume of our Proceedings, which we dedicate to his memory, is not in any other sense a special issue. Apart from his own paper (the first chapter of a new book which he was preparing) it contains only papers which have been submitted in the normal way. One reason for this is to avoid the inevitable time-lag involved in the production of a volume of specially commissioned articles by colleagues, but at the same time there seems to be a certain appropriateness in this solution, of which I feel sure that Terence himself, with his characteristic self-effacing modesty, would fully have approved.

One of his most constant preoccupations, one which, as President of the Prehistoric Society, he forwarded as much as possible, was his concern that younger scholars should be afforded the fullest opportunity of displaying their talents, and I am certain that he would have been pleased to see how largely they figure in this volume. The variety of the contents of this issue would no doubt also have met with his full approbation. A number of the papers published here relate directly to various aspects of his own wide range of interests. Such are the study of aspects of Celtic art by Dr O-H. Frey; the report by Terry Manby (once his student) on the excavation of the Kilham long barrow; and C. J. Balkwill's consideration of the evidence obtainable from cemeteries of the later prehistoric period in the Rhine valley, among others. Others again, which have no such obvious direct link with his own work, would still have attracted his interest and enthusiasm; but above all it seems to me that he would have preferred to feel that he was remembered in a context of active research rather than one of pious hagiography.

May 1976

John D. Evans 


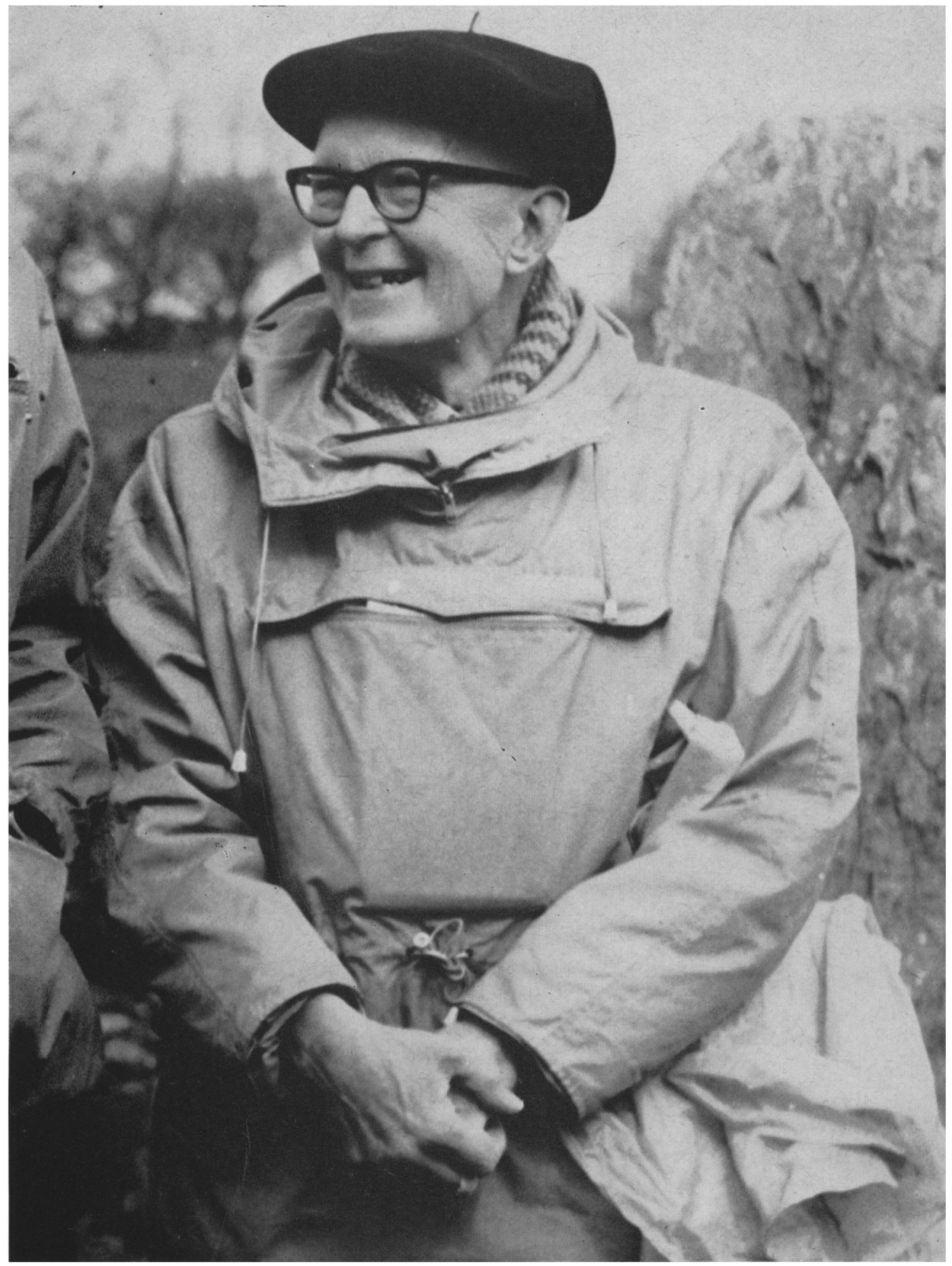

T. G. E. POWELL President, Prehistoric Society I970-1974 (Photo A. L. Selkirk) 